Sensibility, Self-Control, and Friendship in the Writings of the Princess of Carignano, Caluso and Alfieri

\title{
Aria Zan Cabot
}

\section{(2) OpenEdition \\ Journals}

Electronic version

URL: http://journals.openedition.org/aes/1939

DOI: 10.4000/aes.1939

ISSN: 2258-093X

Publisher

Laboratoire LISAA

\section{Electronic reference}

Aria Zan Cabot, «Sensibility, Self-Control, and Friendship in the Writings of the Princess of Carignano, Caluso and Alfieri », Arts et Savoirs [Online], 11 | 2019, Online since 15 July 2019, connection on 05 September 2019. URL : http://journals.openedition.org/aes/1939; DOI : 10.4000/aes.1939

This text was automatically generated on 5 September 2019.

Centre de recherche LISAA (Littératures SAvoirs et Arts) 


\section{Sensibility, Self-Control, and Friendship in the Writings of the Princess of Carignano, Caluso and Alfieri}

Aria Zan Cabot

SENSIBILITÉ. (Morale.) Disposition tendre et délicate de l'âme, qui la rend facile à être émue, à

être touchée. La sensibilité d'âme, dit très-bien l'auteur des mœurs, donne une sorte de sagacité sur

les choses honnêtes, et va plus loin que la pénétration de l'esprit seul. Les âmes sensibles peuvent, par vivacité, tomber dans des fautes que

les hommes à procédés ne commettraient pas ; mais elles l'emportent de beaucoup par la quantité des biens qu'elles produisent. Les âmes sensibles ont plus d'existence que les autres : les biens et les maux se multiplient à leur égard. La réflexion peut

faire l'homme de probité ; mais la sensibilité fait

l'homme vertueux. La sensibilité est la mère de

l'humanité, de la générosité ; elle sert le mérite, secourt l'esprit, et entraîne la persuasion à sa suite.

Louis de Jaucourt, Encyclopédie ou Dictionnaire raisonné des sciences, des arts et des métiers. ${ }^{1}$

Much has been written on the notion of sensibilité in Enlightenment culture ${ }^{2}$. As described by David J. Denby, "sensibility" was a versatile concept that not only figured in the period's literature, philosophy, and medicine, but was also central to "Enlightenment thinking about society, sociability, and solidarity among individuals." ${ }^{3}$ The notion's polysemous quality is illustrated by the presence of two entries on sensibility 
(physiological and moral) in the fifteenth volume of the Encyclopédie (1765): alongside Henri Fouquet's much longer Encyclopédie entry on physiological sensibility (in which the uterus is posited as a locus of sensibility that helps to explain its heightened presence in women), Louis de Jaucourt provided a brief definition of moral sensibility in which he emphasized the "delicate and tender disposition" of sensitive souls and their tendency "to make mistakes that men of reason would never commit." Not surprisingly, this has led to a range of scholarly considerations of gendered notions of sensibilité in English, French, and (to a slightly lesser extent) German literature, including varied observations on sensibility's relation to intellectual endeavor. According to historical accounts of the French and British contexts, while male intellectuals sought to cultivate literary and social forms of sensibility, women were criticized as being too masculine if their writings or public personae lacked a certain requisite "feminine" sensibilité: that is, the sort of delicacy of expression held to arise from the putatively "soft", "sensuous", passive and womb-centered constitution of the female body ${ }^{4}$. Yet, relatively little attention has been paid to how Italian writers confronted, or were confronted by, questions of sensibility in both its moral and bodily significations in their social relationships and writings.

This article will address several questions related to gendered notions of sensibility, selfcontrol, and friendship in the Italian literary tradition through a case study of the life and works of Marie Joséphine Thérèse de Lorraine Harcourt Armagnac, Princess of Carignano (1753-1797), a woman of French descent who spent most of her adult life in Turin and became prominent in Italian literary circles, and her personal and poetic ties with two prominent male intellectuals, Tommaso Valperga di Caluso and Vittorio Alfieri. Through their personal and poetic ties, these writers explore specific aspects of sensibility, the tension between passion and reason, and the correlation between friendship, sympathy, and literary activity. While Carignano and Caluso's amitié amoureuse offered them a "middle way" between friendship and passion, Carignano and Alfieri's private autobiographical narratives were both written with the explicit aim of artistic and moral refinement.

3 My analysis has two principal aims: first, to situate the Princess of Carignano's writings, and those of major figures of the Italian Enlightenment, in a broader moralist and philosophical tradition than the one in which they have been traditionally considered; and, second, to highlight some striking parallels between Carignano's and Alfieri's autobiographical projects, particularly with regard to their linguistic and gender/genre fluidity, and the ways in which their understanding of moral and artistic perfectibility was influenced by contemporary notions of sensibility. Specifically, if sensibility, according to Jaucourt's definition, is associated to varying degrees with both an ideal femininity (the mother of humanity) as well as an ideal masculinity (that which makes men "virtuous", stemming from the Latin vir, for man), it makes sense that the very notion of sensibility would be central to literary projects of moral self-improvement and perfectibility. At the same time, as the following analysis of the literary exchanges between Carignano, Caluso, and Alfieri will suggest, sensibility was viewed to be as much a hindrance as a merit, and a source of tension between the soul (passions) and the mind (reason). 


\section{The Princess of Carignano and her Recueil de portraits (1771)}

4 The princess of Carignano, known in Italy as Giuseppina di Lorena-Carignano, was a prolific translator and writer of travel accounts in both French and Italian. Although none of her works were published during her lifetime, her philosophical, historical and scientific treatises, novels, and dramatic works circulated among her friends and the literary circles with which she was affiliated. A descendant of the Lorraine family (which played an important political role in eighteenth-century Austria, Italy, and France), she left her family at the age of fifteen for an arranged marriage to Vittorio Amedeo II, Prince of Carignano, of the House of Savoy. Upon her arrival in Turin in November of 1768, she quickly became active in Piedmontese cultural circles. Her husband's death, which occurred when she was only twenty-seven, provided her with additional freedom to interact with many Enlightenment figures in Italy and abroad, including Cesare Beccaria, Pietro and Alessandro Verri, Vittorio Alfieri, Giuseppe Parini, Jean-Jacques Rousseau, Voltaire, and Benjamin Franklin, and to form friendships with prominent salonnières ${ }^{5}$.

5 The princess is an interesting figure to study not only because of her liminal geographic and cultural position between France and Italy, but also because of the wide range of genres that she employed to explore questions related to sensibility, to craft an elite cultural identity, and to work toward her own ethical and aesthetical (moral and linguistic) betterment. Among the variety of genres with which she experimented, her fictional works are of particular interest with regard to the princess's understanding of sensibilité. As Denby has observed, the sentimental novel was one of the "major sites" for exploring and celebrating sensibility and the two main "thematic strands" of the genre

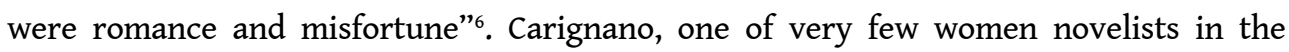
Italian peninsula at the time, exemplified those strands in her novels by featuring young female protagonists who eschew passionate love as an obstacle to intellectual freedom.

6 For the purposes of the present study, however, Carignano's non-fictional works are of particular interest, and specifically her Recueil de portraits (1771), which opens with a literary self-portrait that gradually assumes the appearance of a treatise on the passions, and her Reflexions sur le suicide (1772), a sixty-five-page defense of suicide. The thematic and chronological contiguity between these works opens a unique dialogue between creativity, autobiography, and moral philosophy; moreover, these distinct narrative forms provided the princess with different means of exploring the darker areas of her psyche. The princess's "Portrait $1^{\mathrm{er}}$ de l'auteur de ce recueil fait en 1771" (hereafter "Portrait") is the first of eleven literary portraits in the Recueil de portraits faits par la P. de $C$., which she perhaps intended to publish under a pseudonym and which featured classical figures (Hector, Aeneas, and famous women from antiquity), but also personal friends and contemporary intellectuals ${ }^{7}$. Written in French three years after her arrival in Turin, Carignano's self-portrait, which was never intended for distribution among a wide audience, is one of the very few significant women's autobiographical narratives written in the Italian peninsula during this period. As the princess explicitly states, her Recueil de portraits was inspired by the French tradition of literary portraiture, and specifically the Duchess of Montpensier's Divers portraits $(1659)^{8}$. However, she was also clearly influenced by earlier traditions of literary portraiture and, as might be expected given her social standing, her descriptions of her daily activities are reminiscent of those typically 
included in courtly autobiographies. She describes her training in painting, music, and horseback riding, along with her attendance at dances, social gatherings, and horse races ${ }^{9}$ . She also describes reading and writing as her most beloved pastimes:

La lecture surtout remplit [le temps] de la manière la plus analogue à mon goût, surtout celle des livres de morale et de poésie. Je n'aime pas moins à écrire qu'à lire, tantôt ce sont mes réflexions tantôt des notes sur ce que j'ai lû d'autrefois, je m'amuse à jetter sur le papier les diverses idées qui me passent par la tête sur des objets presque toujours sérieux. ${ }^{10}$ (« Portrait », 10)

While Giuseppina does not provide detailed descriptions of her literary activity in the "Portrait», she did keep a meticulous record of her lectures, providing titles of books fundamental to her education between 1765-1779, starting when she was twelve ${ }^{11}$. Her list includes various historical and philosophical texts, the works of Claude Adrien Helvétius, Michel de Montaigne, French naturalist George-Louis de Buffon, David Hume, and Isaac Newton, classical literature from Homer to Seneca, Cicero and Virgil, Plutarch's Lives, which she had read by 1769, the lives of illustrious men from Cicero to Cardinals Richelieu and Mazarin, epistolary works from Pliny to Madame De Sévigné, and travel books ${ }^{12}$. She also carefully documented her studies of Italian literature and theater in her letters and notebooks, which contain excerpts and her own French translations of Dante and Petrarch and of eighteenth-century playwrights such as Pietro Metastasio, Francesco Albergati Capacelli, and Vittorio Alfieri ${ }^{13}$.

Within the "Portrait», however, Giuseppina chooses not to emphasize her education. Instead, she focuses on exploring her psyche, and views the writing process primarily as an instrument for self-examination and self-improvement:

Ce qui me confirma le plus dans ce project fut la pensée que ce me serait une occupation d'autant plus utille qu'en m'obligeant à sonder les replis de mon âme et à faire un examen sérieux de moi-même je puiserait dans cette connoissance les moyens de me corriger de bien de déffauts. ${ }^{14}$

9 As evident in this passage, and unlike her classical and contemporary models of literary portraiture, Carignano does not present an external reader with moral exempla he or she can follow; rather, she posits her own mind as a text to be read, analyzed, and scrutinized for its imperfections. She first provides a list of her shortcomings and their causes. She attributes her "mauvaise humeur" to an incorrigibly lively spirit and acknowledges that previous attempts to improve her character had been unsuccessful:

La mienne est d'autant plus difficille à deffinir qu'elle n'est pas égalle et l'on n'en sera pas étonné lorsque je dirai que mon esprit et mon imagination, étant vive et ardente, la vie que je me suis trouvé obbligé de menner, les personnes avec lesquelles j'en passe la plus grande partie et les contrarietés que j'y ait portée au sérieux et à la réflexion; mais cette habitude n'est pas encore assez forte en moi pour y changer entièrement le caractère que j'ai reçu de la nature. («Portrait », 4)

Among her greatest weaknesses are a prideful reluctance to rely on the whims of others, an almost religious exaltation of freedom and independence, and a strong sense of amourpropre, the "compagnon fidèle" of all her words and deeds ${ }^{15}$. The emphasis on this particular nexus of characteristics - pride, freedom, amour-propre - helps to illustrate why Luisa Ricaldone has identified in Carignano's other written works an attempt to shape an ideal female character founded on "virile" traits ${ }^{16}$. The princess herself (in a letter to Italian clergyman and antiquarian, Paolo Maria Paciaudi, with whom she engaged in a long epistolary relationship) laments the social limitations on women that required her to suppress her impulses towards self-expression and "glory": "Pour nous pauvres femmes notre première vertu est de ne point faire parler de nous et nos talens sont 
toujours si restrints par notre delicatesse notre education notre position [...] qu'il faut donc renoncer à la gloire et suivre la raison. $»^{17}$ Giuseppina is acutely aware of her status as a noblewoman and its incompatibility with her literary aspirations. However, her selfexhortation to « suivre la raison » is also part of a larger cultural debate over the tension between reason and passion. For the princess, the most effective means of gaining selfcontrol is to cultivate rational, elective friendships while avoiding the impulse towards passionate love:

Je veux bien avouer que l'amour, cette passion que je méprise et crains n'est cependant pas un sentiment que je sois incapable de sentir, mais [...] je crois pouvoir répondre non de ne jamais aimer, mais de combattre si bien mes penchants que, si je ne vurrai pas à bout de le détruire je saurai aumoins les cacher à quiconque en sera la cause. ${ }^{18}$ ( Portrait, 7 )

In both her fictional works and the "Portrait», Carignano distances herself from traditional models of female aristocracy by rejecting vanity, frivolity, and love in favor of education, reason, and the freedom to socialize with men of letters from a position of equal footing, and by associating friendship with more lasting and democratic forms of interaction than passionate love ${ }^{19}$. These themes reflect some of the ideas promoted by Enlightenment-era moral reformers, including the notion that physical well-being and happiness depended on the ability to control one's passions ${ }^{20}$. Carignano's views also challenge what Dena Goodman has called the historical "belief in women's incapacity for friendship" ${ }^{21}$.

The danger of passionate love was a frequent and often playful topic of discussion among Carignano and her friends; in homage to Goethe's ill-fated protagonist, she named one of her pet dogs "Werther", for whom she commissioned a statue to be erected in her garden with inscriptions in Hebrew, Greek, Latin, and Italian ${ }^{22}$. Yet, the fate of those who had fallen prey to their passionate impulses was also a matter of serious concern for the princess. In the "Portrait», she describes her willingness to forgo one of life's greatest pleasures to protect herself from the worst grief:

Je sens que par cette conduitte je me prive de ce que bien des gens regardent comme le plus doux plaisir de la vie, mais je mérite ${ }^{23}$ aussi les chagrins les plus cuisants qu'on y puisse éprouver et le gain à mon avis l'emporte de beaucoup sur la perte, car soit faiblesse en moi ou raison, j'avoue que j'aime moins les plaisirs que je ne crains; ces genres de peines qui affectent réellement le coeur et qu'une âme sensible rencontre plus souvent dans l'amour qu'elle n'y trouve de jouissance, je pourrais aisément le prouver mais comme ce n'est pas un traité contre cette passion que je pretend écrire j'en revins aux raisons qui m'en ont donné tout déloignement. Elles son tirées de mes principes d'un grand attachement à mes devoirs, à ma reputation et surtout d'une extrême sensibilité, qui me fait regarder comme le plus grand des malheurs de rompre avec ce que j'aime ou de n'en être pas aimé comme j'aimerais, malheurs qu'il est aisé de prévenir en amitié par un bon choix. (« Portrait », 7-8)

13 Carignano promises that her intention remains that of creating a literary self-portrait and not a treatise against passionate love, yet she is so drawn to the latter topic that it begins to overtake her project:

[C]'est assez me tendre sur un objet dont je n'aurais pas parlé avec tant de détail si l'opinion que l'on a de mon coeur m'avait obbligé à en faire la justification plutôt que le portrait et si j'ai desiré montrer que je ne suis pas incapable d'amour; je désire encore plus prouver que je suis capable d'amitié et peut être même de mériter celle des autres. (« Portrait », 8) 
The remainder of the « Portrait » continues to be centered on rejecting violent passion in order to pursue more active and voluntary forms of social interaction guided by reason. While this detour from the original intent of the «Portrait » distances the princess's narrative from traditional definitions of literary portraiture and autobiography, it provides a key to understanding some autobiographical elements in her other works, most notably her treatise, Réflexions sur le suicide. Though the Réflexions are often dismissed as an impersonal compilation of musings gleaned from other philosophical works, including Montesquieu's Lettres Persanes (1721), Maupertuis's Essai de philosophie morale (1749), and the French translation of David Hume's "Of Suicide" (1755), the treatise offers a rare female perspective on the debate over passions found in many European works of the period, including Goethe's The Sorrows of Young Werther (which appeared in French translation in 1775) ${ }^{24}$. Giuseppina even inscribes her Réflexions within an autobiographical narrative frame, prefacing the text with an explanation of the circumstances in which she wrote the treatise (she tells the reader that, unable to publicly challenge her mother on the matter, she has retreated to her room to write her defense of suicide). Thus, the circumstances surrounding the writing of both the « Portrait» (a private project of self-improvement) and the Réflexions (the formulation of a rational rebuttal to an impassioned public debate) illustrate Giuseppina's concrete attempts to suppress a natural inclination towards violent passions: as she puts it, «la violence de passions où je suis naturellement portée » (« Portrait »,12).

\section{“Le Coeur très-sensible à l'amitié": Carignano's Friendships with Caluso and Alfieri}

15 In Brotherly Love: Freemasonry and Male Friendship in Enlightenment France (2014), Kenneth Loiselle writes that among the various nuances acquired by the term sensibilité in the eighteenth century was a strong association with friendship ${ }^{25}$. Yet, as evident in Loiselle's title, such relationships were often considered to be possible only between men. For example, in his Essays (1595), a landmark work in the history of western literary selfportraiture, Montaigne goes beyond notions of ordinary "acquaintanceships and familiarities" to imagine a relationship in which "souls mingle and blend with each other so completely that they efface the seam that joined them", and yet he is careful to qualify this bond as a form of "brotherly affection", different from "affection for women, even though it is the result of our choice"26. Friendship "is enjoyed according as it is desired" and "bred, nourished, and increased only in enjoyment, since it is spiritual, and the soul grows refined by practices" ${ }^{27}$. Relationships with women, on the other hand, are associated with "ardor", and are "more active, more scorching, and more intense", and "undulating and variable" 28 . Montaigne also asserts that in general "the ordinary capacity of women is inadequate for that communion and fellowship which is the nurse of this sacred bond; nor does their soul seem firm enough to endure the strain of so tight and durable a knot"29.

16 Exactly because this gendered distinction between friendship and love persisted through the eighteenth century, the Princess of Carignano's quest to master the passions (and her insistence that she is indeed "capable of friendship") required a certain amount of gender fluidity, a resistance to traditional associations of sensibility and femininity, and a suppression of her own impulses. According to the Memoirs of the diplomat Louis Dutens 
(1730-1812), who met the princess while working at the Court of Turin, she was quite successful in her efforts to avoid "the dangers of passion":

Elle avoit l'esprit éclairé, plein de grâces, vif, juste et solide, prompt à concevoir tout ce à quoi elle l'appliquoit; son entretien étoit gai ou sérieux, selon l'occasion, mais toujours agréable. Elle avoit l'âme bonne, généreuse, noble, élevée, le cœur très-sensible à l'amitié; peut-être aussi l'eût-il été à l'amour, si l'extrême délicatesse de ses sentiments ne lui eût rendu le choix d'un objet trop difficile. Cette disposition, et une certaine fierté de caractère, souvent garde de la vertu de la plupart des femmes, avoient toujours préservé le cœur de la princesse des dangers de cette passion; mais si elle ne se livroit pas à ses attaques, elle aimoit à en faire le sujet de la conversation, et personne, mieux qu'elle, ne savoit analyser le sentiment. La Princesse de Carignan aimoit aussi à proposer dans le discours des sujets à traiter, des questions à résoudre, et j'avois la satisfaction de voir qu'elle préféroit mes solutions à celles de tout autre. Ce fut pour elle que j'écrivis l'histoire de miss Ray [...] et je la produisis, pour remplir le titre des funestes effets de l'amour qu'elle avoit désiré que je traitasse. ${ }^{30}$

17 In accordance with this description, the princess cultivated a number of judiciously calibrated personal friendships with Italian intellectuals. The poets Giuseppe Parini and Vittorio Alfieri both addressed her in verse, and she shared a particularly strong and publicly acknowledged amitie amoureuse with the Torinese abbot Tommaso Valperga di Caluso (1737-1815). Following her arrival in Turin, she often invited Caluso, who was also a mathematician, scholar of Hebrew and Arabic, and member of Piedmont's literary élite, to her residence at Racconigi ${ }^{31}$. Caluso in turn dedicated various poetic compositions to the princess to commemorate occasions such as travels, birthdays, and deaths in the family, and they named each other as the respective heirs of their personal libraries ${ }^{32}$.

Caluso's most famous poetic work, the Omaggio poetico di Euforbo Melesigenio alla Serenissma Altezza di Giuseppina Teresa di Lorena Principessa di Carignano (1792), is dedicated to Giuseppina and includes poems about her travels from Genoa to France in 1781 and her pilgrimage to the famed site of Petrarch's retreat in Vaucluse. In the opening stanzas of the poem "La Ragione Felice" (1779), which is included in the collection and consists of six cantos in terza rima, Caluso notes that he was inspired by his muse's familiar face ("noto volto") and cultured mind, and describes the "beautiful chorus of masculine virtues" gathered in her "female heart" ${ }^{33}$.This image of the princess coincides with her self-description in the "Portrait", where she stresses that she is endowed with a "fortitude, courage, and strength" not usually attributed to women:

Quoique la fermeté le courage et la force d'esprit ne soyent pas regardés comme l'appanage de mon sexe [...] je crois les avoir assez montrées dans les suffrances et les petites occasions qui se rencontrent journellement pour fair juger quelles sont dans mon caractère, n'étant pas d'ailleurs susceptible de ces craînteries pueriles et foiblesses que l'on attribue aux femmes et encore moins de cette coquetterie si commune parmi elles [...] si je cherche à plaire, c'est par mon caractère et mon esprit. $^{34}$

19 Taken together, the emphasis in both "La Ragione Felice" and the "Portrait" on Carignano's gender-fluid attributes attests not only to her moral fortitude and intelligence but also to the egalitarian nature of her relationship with Caluso. Both writers suggest that reason should be employed to dominate the passions and both posit extreme emotions as the cause of suffering whereas friendship is the base of true happiness. However, Caluso acknowledges in the first canto the difficulty of cultivating reason against the natural weaknesses and blind emotions of the human spirit: as in the "Portrait », the poet's personified Reason ("Ragione"), the "inexpert" ruler, is ultimately 
destroyed by the empire of her opponent, Desire ("Voler »), described in the fifth canto as a despotic sovereign ("dispotico sovrano") ${ }^{35}$. Thus, as Milena Contini has observed, Caluso's view of reason is twofold: he outlines a process of acquiring happiness through reason, but also highlights the limitations on humans' ability to control their own impulses ${ }^{36}$.

Caluso's collection and his intimate relationship with its dedicatee resonated among friends and fellow poets; in 1796, Vittorio Alfieri had himself portrayed in an oil painting by François-Xavier Fabre with one hand resting on a copy of Caluso's Omaggio poetico opened to display the third canto of "La Ragione Felice" ${ }^{37}$. The following year, on the occasion of Giuseppina's untimely death at the age of forty-four, Alfieri sent a letter to Caluso to express his condolences and warn his friend that he would probably not be able to resume his literary activities after such an emotional blow: "Non vi lusingate però per un pezzo di potere attendere allo studio. Voi leggerete lei, vedrete lei, troverete lei in ogni azione e pensiero vostro, e senza pure averla giammai." ${ }^{38}$ Alfieri's emotionally charged sympathies are written in an unsteady hand, with many words crossed out as the poet struggled to imagine the despair he would feel in the event of a similar loss, which he likens to a violence of reason ("violenza di ragione"):

Se mai è destino che io sopraviva, non so in quale età, in quali disposizioni d'animo e di corpo mi potrebbe ritrovare tal disgrazia; ma certamente qualunque violenza di ragione valessi a fare alla mente, non ne potrei mai fare pur tanta al core, ed al corpo, che io non soccombessi ben presto. ${ }^{39}$

Here, we find a representation of friendship, sympathy, and loss that has, once again, a strong literary precedent in Montaigne's Essays, one of the works that Alfieri held most dear. In his autobiography, which he was still in the process of writing at the time of the princess's death, Alfieri describes how, during his travels from Milan and Venice to Vienna in 1769, the Essays had provided him with "the greatest utility". He goes on to claim: "It is to them perhaps that I owe the little capability of thinking which I possessed." ${ }^{40}$ Later in the autobiography, Alfieri describes Caluso as a "living Montaigne", and writes that Caluso's "friendship and society" was "the greatest utility in tranquillizing" his mind ${ }^{41}$. Thus, there is no doubt that as he composed his letter of condolence to Caluso in 1797, Alfieri would have had in mind the circumstances surrounding the composition of the Essays, or rather the death of Montaigne's close friend, Etienne de La Boétie ${ }^{42}$. Montaigne's "Of Friendship" in fact ends, much like Alfieri's letter, with a lament (made through a citation of Catullus) on the pain of losing a dear friend and the consequences of such a loss on one's intellectual and literary activity:

Brother, your death has left me sad and lone;

Since you departed all our joys have gone,

Which while you lived your sweet affection fed;

My pleasures all lie shattered, with you dead.

Our soul is buried, mine with yours entwined;

And since then I have banished from my mind

My studies, and my spirit's dearest joys. ${ }^{43}$

If Alfieri's lettter is thus less an homage to dispassionate friendship than an impulsive reflection on the emotional devastation caused by the princess's death, this may also have been because the poet, like Caluso, had a personal connection with Carignano that may have contributed to the impassioned tone of his letter. There are several biographical and literary intersections between the two writers; for example, Alfieri's first tragedy, Cleopatra, debuted in 1775 in the Carignano Theater, which had been commissioned in 
1752 by Giuseppina's father-in-law and designed by Alfieri's uncle, the architect Benedetto Alfieri. Beyond their ties with the Piedmontese literary and cultural élite of the 1770s, one might also consider their similar struggles to choose between French and Italian as their primary literary language, and their openness to experimenting with diverse private and public autobiographical forms, which they saw as tools of moral and artistic improvement.

\section{"For Myself, about Myself, and by Myself": The "Portrait" and Alfieri's Giornali (1774-1777)}

Montaigne affirmed of his Essays: "I no more made my book than my book has made me." ${ }^{44}$ The same ambiguity of self-writing, suspended between the writing about oneself and the writing - or invention - of oneself, characterizes both Carignano's and Alfieri's private autobiographical writings. Born to a noble family in Asti, in Piedmont, Alfieri was raised speaking French and received a classical education in Latin. His sole forays into Italian literature were works read on his own, "without method" ${ }^{45}$ and with great pleasure, and his travels to other Italian cities between 1766-1775 further complicated and contributed to his sense of linguistic and political non-belonging. While his independent spirit had sparked his initial enthusiasm for the French Revolution (during the outbreak of which he was living in Paris), disillusionment and disgust eventually led him to leave France in 1792, embrace his Italian identity, and settle permanently in Florence. After writing two early tragedies and his satirical Esquisse du jugement universel (1773) in French prose, Alfieri became committed to mastering literary Italian and increasingly expressed antiFrench sentiments in his writings, most explicitly in his satirical collection of poems and letters, Il misogallo.

Alfieri's early works in French also include a series of private journals, or Giornali (1774-1777), which are often considered a precursor to his autobiography, or Vita (published in Italian posthumously in 1804). The circumstances surrounding the composition of the Giornali are almost identical to those of Carignano's "Portrait": both were private documents, intended for strictly personal use rather than publication, written in French (though Alfieri eventually switched to Italian) in Turin during the early 1770s, and they share some common sources (travel accounts, Plutarch's Lives, and the works of French philosophers $)^{46}$. The private nature of the "Portrait ", written by and for the princess alone, provides readers with a glimpse into Giuseppina's mind and personal life that would have been impossible in a piece of writing intended for publication. It also brings her narrative away from the genres of literary portraiture and autobiography and closer to that of the private journal, adopted by Alfieri. Moreover, while ostensibly adopting distinct narrative forms with unique formal characteristics (private journals and literary self-portraits, respectively), Alfieri's Giornali and Carignano's « Portrait " reveal fluidity, if not instability, in terms of genre and content ${ }^{47}$. Alfieri, for example, never uses the French term journal at all, and uses the Italian giornale only once, on the last page of the diary ${ }^{48}$. Instead, he employs more oblique, descriptive phrases to define his project, which he calls a "study" of himself ${ }^{49}$.

Both authors saw their private narratives as a tool of ethical and aesthetical (linguistic and artistic) betterment. Although French was Giuseppina's native language, she expresses awareness of the numerous stylistic, grammatical, and lexical imprecisions in 
the "Portrait" and attributes these flaws not to a lack of ability or education, but to her limited interest in correcting a piece of writing intended only for personal use:

Tous ces différents ouvrages pourraient être écrits avec infinement plus de collection [sic: correction] et d'élégance qu'il ne sont, mais je n'ais pas la patience de les écrire avec soin ni de les corriger, d'autant plus que mon intention n'est pas qu'ils soyent vus, et d'ailleurs il faudrait toujours recommencer, car à mon âge l'on acquiert tout les jouis [sic: jours] des idées et l'on est souvent bien étonné de celles que l'on a eu par le passé; ainsi je ne les conserve que pour juger moi-même du progrès de mon esprit et comparer ma façon de penser présente à la passée..$^{50}$

Like the princess, Alfieri planned to use his Giornali to conduct "a healthy examination" of himself, correct his flaws ( l'envie de me corriger $»^{51}$ ), satisfy his amour-propre, improve his writing, and remedy his stylistic shortcomings. In his first entry, he describes the "method" of journal writing as a possible means of perfecting himself:

Se rendre conte à soi-même des actions de chaque jour, n'est le plus souvent qu'un temps perdu, parce qu'on répète facilement le lendemain les mêmes deffauts dont on a rougi le soir d'avance. Plusieurs philosophes ont cependant regardé cette méthode comme très bonne, en ce que tôt ou tard un homme de sens doit se corriger, de ce qui doit nécessairement lui déplaire, en se regardant aussi souvent dans ce fidèle miroir, car personne ne nous connoît mieux que nous-mêmes, et l'on se fuit ordinairement, parce que chaque homme est malheureusement dans le cas de ne point trouver de plus mauvaise compagnie que soi-même; n'importe ! je m'en vais voir si en m'analysant près je pourrois me tolérer [...] Que d'inutilités épargnées, si la mode prenoit !52

On the first page of the Italian portion of his journal, begun in April of 1777, he attributes the two-year interruption of his project to linguistic obstacles and the difficulty of describing his flaws, but expresses renewed hope in his endeavor:

Questo salutare esame di me stesso interrotto da più di due anni, in parte perché la difficoltà d'esprimermi in toscano era somma, e la natural ripugnanza a sparlar di sé non minore, mi si para di bel nuovo innanzi come efficace mezzo di correggermi un cotal poco, e di formarmi a un tempo stesso lo stile..$^{53}$

Years later, in his Vita, Alfieri carefully documents his cultural and linguistic difficulties with both French and Italian. Describing his early tragedies, Filippo and Polinice, he laments:

Ma per mia somma disgrazia, elle si trovavano concepite e nate in prosa francese, onde rimanea loro lunga e difficile via da calcarsi, prima ch'elle si trasmutassero in poesia italiana. $\mathrm{E}$ in codesta spiacevole e meschina lingua le aveva io stese, non già perchè io la sapessi, nè punto ci pretendessi, ma perchè in quel gergo da me per quei cinque anni di viaggio esclusivamente parlato e sentito, io mi veniva a spiegare un po' più, ed a tradire un po' meno il pensiero mio; che sempre pur mi accadeva, per via di non saper nessuna lingua, ciò che accaderebbe ad un volante dei sommi d'Italia, che trovandosi infermo, e sognando di correre di competenza de' suoi eguali o inferiori, null'altro gli mancasse ad ottener la vittoria se non se le gambe. ${ }^{54}$

Yet he also describes his lifelong struggle to "master" Tuscan (literary) Italian and even at the end of his life, writing of the summer of 1803 , he claims: "in order to avoid conversing in the French language, I religiously shunned every society in which it was spoken, yet I did not succeed in Italianizing myself" 55 . Similar to Alfieri's rejection of French in an effort at "Italianization", Carignano's linguistic difficulties and irregular French have been attributed to an existential crisis caused by her forced relocation from France to Piedmont, her solitary personality, and societal expectations that women's intellectual pursuits remain private ${ }^{56}$. 

anticipatory example of self-writing in the Italian literary tradition. However, it would be more accurate to place both the Giornali and the « Portrait » within a larger body of emergent forms of autobiographical writing focused not only on describing, but also improving and inventing oneself. Within this network, for example, one might also consider Giuseppe Pelli Bencivenni's eighty-volume diary, or Efemeridi (1759-1808). Like Alfieri and Carignano, Pelli, who was the director of the Uffizi Gallery in Florence from 1775-1793, intended for his diary to be kept private for personal use only ${ }^{57}$. Taken together, these works illustrate the fluidity between various forms of private self-writing aimed at disclosing one's "real" self through self-analysis and self-construction ${ }^{58}$. Whereas diaries had often served as professional, family, or historical records, these documents show how elements of private writing in the late eighteenth century were later directly incorporated into public forms of autobiographical writing, especially in the case of Carignano's fictional works and Alfieri's Vita ${ }^{59}$.

Ultimately, at the heart of the Princess of Carignano's « Portrait » is her concerted effort, not to abandon a weakness (passions) in favor of a strength (reason), but rather to identify through reading, writing, and friendships an ideal means of moral selfimprovement, which seems to be contingent on striking the proper balance among these forces. The « Portrait » and its parallels with the writings of major contemporary Italian writers also highlight the princess's intermediary position between French and Italian culture, and between new currents of sensibility and Enlightenment ideals of reason, rationality, progress, peace, and intellectual freedom. Her juxtapositions of friendship and love demonstrate her active and precocious role in the debate over passions, while her efforts to negotiate the thin line between her (feminine) "extreme sensibility" and (masculine) desire to "follow reason" are exemplary of the complex relationship between reason and passions that contemporary scholars of the eighteenth century have warned against reducing to a simple dichotomy ${ }^{60}$. Carignano's simultaneous interest in and rejection of passionate love not only helps to capture an important cultural transition from a female perspective, but also shows how the private writings of women can enrich wider scholarly discussions of literary self-portraiture and intellectual autobiography in France and Italy, from Montaigne to Rousseau.

\section{NOTES}

1. Louis de Jaucourt, «Sensibilité (Morale) » in Encyclopédie, ou Dictionnaire raisonné des sciences, des arts, et des métiers, ed. Denis Diderot \& Jean Le Rond d'Alembert, Paris, Chez Briasson et al, 1751-1772, 17 vols.; vol. 15, 1765, p. 52. Citation is taken from the University of Chicago: ARTFL Encyclopédie Project, Autumn 2017 Edition, ed. Robert Morrissey and Glenn Roe, http:// encyclopedie.uchicago.edu/.

2. See, for example, historian Stephen Gaukroger's chapter on "Sensibility" in The Routledge Companion to Eighteenth-Century Philosophy, ed. Aaron Garrett, London, Routledge, 2014. A special issue of the Intellectual History Review was also dedicated to this topic: Sensibility in the Early Modern

Arts et Savoirs, $11 \mid 2019$ 
Era: From Living Machines to Affective Morality, ed. Anik Waldow, Intellectual History Review, vol. 25, n o 3, 2015, p. 255-372.

3. David J. Denby, "Sensibility", Encyclopedia of the Enlightenment, ed. Alan Charles Kors, Oxford, Oxford University Press, 2002, current online version: Oxford Reference, 2005, http:// www.oxfordreference.com (accessed August 10, 2017). Denby maintains that, as a literary movement, sensibility is "exemplified in such authors as Laurence Sterne, Samuel Richardson, and Jean-Jacques Rousseau", whose works are marked by "the celebration of emotion and the public shedding of tears". See also Denby, Sentimental Narrative and the Social Order in France, 1760-1820, Cambridge, Cambridge University Press, 1994; and John Mullan, Sentiment and Sociability: The Language of Feeling in the Eighteenth Century, Oxford, Clarendon Press, 1988.

4. Anne Vila, Enlightenment and Pathology: Sensibility in the Literature and Medicine of EighteenthCentury France, Baltimore, Johns Hopkins University Press, 1998, p. 225-257. Male sensibility was, by contrast, energetic and intellectually oriented according to the dimorphic model of the sexes that developed in the final decades of the eighteenth century. Vila argues that in the earlier part of the century, French writers "did not polarize sensibility in relation to sex and gender nearly as much as did their British counterparts", and that "even the most hard-boiled philosophes prided themselves on their sensibility and saw nothing unmanly about cultivating this quality" (Ibid., p. 3). Dena Goodman, however, has suggested that the pendulum swung less generously for women, who were often criticized for being "too masculine" if they lacked the sensibility associated with femininity, whereas male intellectuals "to attain their full humanity [...] needed to be sensible as well as rational"; Goodman, Becoming a Woman in the Age of Letters, Ithaca, Cornell University Press, 2009, p. 53.

5. See Gaetano Gasperoni, Giuseppina di Lorena Principessa di Carignano, Turin, G.B. Paravia, 1938; and Luisa Ricaldone, "Giuseppina di Lorena-Carignano, ancora", in Lumi inquieti: Amicizie, passioni, viaggi di letterati nel Settecento. Omaggio a Marco Cerruti, Turin, Accademia University Press, 2012, and "Una letterata a corte: Giuseppina di Lorena Carignano", in L'alterità nella parola. Storia e scrittura di donne nel Piemonte di epoca moderna, ed. Cristina Bracchi, Turin, Thélème Editrice, 2002.

6. Denby, "Sensibility" (op.cit.). As mentioned earlier, Denby's discussion is focused on French and English novels, and specifically Richardson's Pamela (1740-1741) and Clarissa (1747-1748), Sterne's Tristram Shandy (1760-1767) and Sentimental Journey (1768), Jane Austen's Sense and Sensibility (begun in 1797 and published in 1811) and Rousseau's La nouvelle Héloïse (1761).

7. The « Portrait » occupies the first nineteen of the sixty-seven pages of the manuscript, which is found in Turin's Biblioteca Reale and was published for the first time in Ricaldone's Scelta di inediti di Giuseppina di Lorena-Carignano, Turin, Centro studi piemontesi, 1980. I cite the text exactly as it appears in this edition, which preserves Carignano's agreement and orthographic errors, and missing accents.

8. «Les portraits que j'ai lus dans les mémoires de Mlle de Montpensier me firent venir l'idée d'écrire le mien » (p. 3). Indeed, literary portraiture was popularized by French salonnières like the Duchess of Montpensier (1627-1693). One of the most well-known Italian women literary portraitists of the eighteenth century was Isabella Teotochi Albrizzi (1760-1836), a prominent salonnière in Venice whose Ritratti immortalized contemporary and historical literary figures, including women writers like the Renaissance Petrarchist Vittoria Colonna.

9. «La peinture la musique m'occupe aussi quelques instants agréablement car je ne sais pas rester sans rien faire [...] je sais jouir des plaisirs plus vifs que ceux que je viens de citer, tel que [...] les fêtes, la chasse et monter à cheval. » (p. 10-11) Such descriptions are standard in women's courtly autobiographies, which gained popularity among European noblewomen starting in the late seventeenth century, such as Anne-Marie-Louise d'Orléans, Duchess of Montpensier (the Grande Mademoiselle), Queen Christina of Sweden, and Leonora Cristina of Denmark.

10. The citations that follow this one contain instances of what may be transcription errors in Ricaldone's Scelta di inediti di Giuseppina di Lorena-Carignano (op. cit.), or simply agreement and 
orthographic errors on Carignano's part («je puiserait $[$ sic] », « je ne vurrai [sic] », « un'espèce [ sic] », etc.). Rather than cluttering the text of this article with repeated indications of [sic], I have elected to allow the reader to see these passages in their authentic, original form as presented in Ricaldone's edition (see note 7).

11. Gasperoni, op. cit., p. 4.

12. Ricaldone, "Una letterata a corte", p. 51-53.

13. See Gasperoni, op. cit p. 4-6 and p. 48, and Ricaldone, Scelta di inediti, p. xii.

14. "Portrait", p. 3.

15. «On peut juger delà que mon humeur n'est rien moins que souple et docile, aussi disais je souvent, que si j'étais née parmi les payens. La liberté et l'indépendence auraient été les divinités que j'aurait choisie pour leur élever des autels.» (p.6); «D'ailleurs j'avouerai que j'ai en moi un'espèce de fierté qui me fait dédaigner de rendre mon bonheur dépendant du caprice d'autrui, fierté bien differente de la hauteur puisqu'elle convient à tous les états et nous est conseillée par la raison et la vertu. » (p. 8); «L'amour propre est mon déffaut favori et habituel, le compagnon fidèle de mes actions et des mes paroles. » (p. 10)

16. Ricaldone, "Una letterata a corte", p. 62.

17. Cited in Luisa Ricaldone, "Tre lettere inedite di Giuseppina di Lorena-Carignano", Studi Piemontesi 12, fasc. 2, November 1983, p. 430.

18. The superiority of friendship over love is also a central theme of the princess's fictional works, L'amour vaincu and Conte moral. La coquette punie par l'amour ou les dangers de la coquetterie, in which friendship is proposed as an antidote to social ills such as vanity and passionate love, which threaten the possibility of intellectual friendships between men and women. Her philosophical essays "Sur l'amour platonique" and "Confronto dell'amicizia con l'amore" (included in Ricaldone's Scelta di inediti) contain similar meditations. See Ricaldone, "La donna forte, l'amica e la riformatrice: il Portrait di Giuseppina di Lorena-Carignano (1753-1797)", in La scrittura nascosta: Donne di lettere e loro immagini tra Arcadia e Restaurazione, Paris, Honoré Champion/ Fiesole, Cadmo, 1996, p. 166-168.

19. The most clearly autobiographical of Carignano's fictional works is her epistolary novel, Les Aventures du Marquis de Belmont écrites par lui même ou les nouveaux malheurs de l'amour, whose protagonist (like the author) is a young, widowed noblewoman who describes her freedom from marriage as "le premier de tous mes bonheurs" (cited in Ricaldone, "Giuseppina di LorenaCarignano, ancora", p. 159). This stance, too, is reminiscent of Montaigne's presentation of true friendship as the least tyrannical of human relationships.

20. On the connection between female happiness and the suppression of passionate impulses, see Elena Brambilla, Sociabilità e relazioni femminili nell'Europa moderna: Temi e saggi, Milan, Franco Angeli, 2013, p. 116-118 and p. 149.

21. Dena Goodman, The Republic of Letters: A Cultural History of the French Enlightenment, Ithaca, Cornell University Press, 1994, p. 84.

22. Tommaso Valperga di Caluso describes composing the distich for the princess's dog in his poem "L'Apoteosi di Verter" ["The Apotheosis of Werther"], in Omaggio poetico di Euforbo Melesigenio alla serenissima altezza di Giuseppina Teresa di Lorena, principessa di Carignano, Parma, Nel regal palazzo, co' tipi Bodoniani, 1792.

23. The word mérite may be a transcription error: Carignano may have originally written m'évite, which would be more logical in this context.

24. As Denby notes, Hume's Treatise of Human Nature (1739-1740) "presented sympathy as the fundamental mechanism whereby the passions of each individual are communicated to others. Passions and sentiment are the very stuff of sociability, and it is sympathy that generalizes them, overcoming differences between individuals" ("Sensibility", op.cit.). For a more detailed contextualization of the Réflexions and Carignano's sources of inspiration (which also include 
letters 21-22 of Part Three of Rousseau's Nouvelle Héloïse), see Ricaldone’s introduction in Il "genio muliebre."

25. Kenneth Loiselle, Brotherly Love: Freemasonry and Male Friendship in Enlightenment France, Ithaca: Cornell University Press, 2014, p. 180 (part of the chapter "Friendship in the Age of Sensibility", p. 156-200).

26. Michel Eyquem de Montaigne, "Of Friendship", in The Complete Essays of Montaigne, trans. Donald M. Frame, Stanford, Stanford University Press, 1965), p. 139; p. 137. «accointances et familiarités ", "De l'Amitié », in Montaigne, Les Essais, ed. Jean Céard, Paris, Le Livre de poche, coll. « La Pochothèque », 2001, p. 290 ; « [Les âmes] se mêlent et confondent l'une en l'autre, d'un mélange si universel, qu'elles effacent, et ne retrouvent plus la couture qui les a jointes » (ibid., p. 291); «De comparer [à la concorde fraternelle] l'affection envers les femmes, quoiqu'elle naisse de notre choix, on ne peut. » (ibid., p. 286)

27. Ibid., p. 137 ; " [L'amitié est] jouie à mesure qu'elle est désirée, ne s'élève, se nourrit, ni ne prend accroissance qu'en la jouissance, comme étant spirituelle, et l'âme s'affinant par l'usage. » (ibid., p. 287)

28. Ibid., p. 137 ; " plus actif, plus cuisant, et plus âpre », " ondoyant et divers ». (ibid., p. 286)

29. Ibid., p. 138 ; « la suffisance ordinaire des femmes n'est pas pour répondre à cette conférence et communication, nourrice de cette sainte couture : ni leur âme ne semble assez ferme pour soutenir l'étreinte d'un nœud si pressé, et si durable ». (ibid., p. 288)

30. Louis Dutens, Mémoires d'un voyageur qui se repose: Contenant des anecdotes historiques, politiques et littéraires, relatives à plusieurs des principaux personnages du siècle, Paris, Bossange, Masson et Besson, 1806, vol. 2, p. 214-215.

31. Gasperoni, p. 39-41. On Caluso's cultural activity and engagement in the moderate Enlightenment climate of the Turinese élite during the 1760s, see Guido Santato, "Un Montaigne vivo", in Nuovi itinerari alfieriani, Modena, Mucchi, 2007, p. 135-174, and Franco Fido, "La ragione felice e altri miti del Settecento", Modern Philology 75, n 1, August, 1977, p. 91-94.

32. On Caluso and Carignano's amitié amoureuse, to borrow Santato's words ("Un Montaigne vivo", p. 135), see Marco Cerruti, Il piacer di pensare. Solitudini, rare amicizie, corrispondenze intorno al 1800, Modena, Mucchi, 2000, p. 43-57; Ricaldone, "Giuseppina di Lorena-Carignano, ancora", p. 154, Scelta di inediti, p. xi, and "Una letterata a corte", p. 50; and Gasperoni, p. 39-41 and p. 78.

33. "Nel femmineo petto/di maschili virtù bel coro accolto". (Caluso, "La Ragione Felice", in Omaggio poetico, p. 6)

34. « Portrait », p. 6.

35. Caluso, "La Ragione Felice", p. 6-7. "Data a principio alla natura umana / Ragion fanciulla, inesperta regina / Di ciechi affetti infra la turba insana, / Or scossa da crudel guerra intestina, / Or disviata di volgari inganni [...] / In pochi, ahi troppo! anco negli ultimi anni / Giunge dal docil cor con certo impero / I furori a bandir, e i pazzi affanni" ["Conferred from the beginning to human nature / Young Reason, inexpert queen / Of blind emotions below the mad throngs, / Now shaken by civil strife, / Now led astray by base deceptions ... So few, alas too much! Even in recent years / It comes from my docile heart with a sure command / the furies to be banished, and the mad breathlessness"]. Unless otherwise noted, all English translations are my own.

36. See Milena Contini, "Il corpo martoriato. L'interesse di Tommaso Valperga di Caluso per quattro atroci fatti di sangue", in Il corpo, l'ombra, l'eco, vol. 7 of Metamorfosi dei Lumi, ed. Clara Leri, Turin, Accademia University Press, 2014, p. 4.

37. Santato, "Un Montaigne vivo", p. 158. Fabre's painting, Vittorio Alfieri e la Contessa Luisa Stolberg d'Albany, is found in the Museo Civico di Torino.

38. "Don't delude yourself that you will be able to dedicate yourself to your studies for awhile. You will read her, you will see her, you will find her in your every thought and deed, and without ever being able to have her again." The letter, dated from Florence on February 20, 1797, was published as "Una lettera di Alfieri per la morte della principessa di Carignano", in Per far di 
bianca carta carta nera: prime edizioni e cimeli alfieriani, Torino, Biblioteca reale, 29 novembre-29 dicembre 2001, ed. Vittorio Colombo, Giovanna Giacobello Bernard, Clemente Mazzotta, and Guido Santato, Savigliano, Editrice artistica piemontese, 2001, p. 146.

39. "As for me, if ever fate would have it that I should live through such a thing, I don't know at what age, in which state of mind and body such a tragedy would find me, but surely whatever violence of reason it would do to the mind, I could never withstand the same in my heart or body, without quickly succumbing." (Ibid., p. 146)

40. Vittorio Alfieri, Life of Vittorio Alfieri. With an Essay by William D. Howells, Boston, James R. Osgood and Co., 1877, p. 152.

41. Ibid., p. 179.

42. In his "Introduction" to The Complete Essays of Montaigne, Donald M. Frame argues that, in the wake of his friend's death, the Essays offer Montaigne a new "means of communication; the reader takes the place of the dead friend" (p.v). Like Caluso, heir to the princess's personal library, Montaigne regarded the inheritance of his deceased friend's books as a symbol of their deep intellectual bond: "I, to whom in his will, with such loving recommendation, with death in his throat, he bequeathed his library and his papers." (“On Friendship", p. 136 ; « moi qu'il laissa d'une si amoureuse recommandation, la mort entre les dents, par son testament, héritier de sa Bibliothèque et de ses papiers » [« De l'amitié », p. 285]).

43. Montaigne, “On Friendship", p. 136 ; « De l'amitié », p. 299-300.

44. Montaigne, "Of giving the lie”, op. cit., p. 504 ; «Je n'ai pas plus fait mon livre, que mon livre m’a fait », « Du Démentir », op. cit, p. 1026.

45. Life of Alfieri, p. 82.

46. Alfieri requested in his will that his journals be burned by his companion and beneficiary, Luisa Stolberg, the Countess of Albany, who for reasons unknown did not respect his wishes. In his autobiography, he refers to Plutarch's Lives as "the book of books" ("il libro dei libri per me"). (Vittorio Alfieri, Vita scritta da esso, ed. Luigi Fassò, Asti, Casa d'Alfieri, 1951, p. 93)

47. It is often held that "modern" autobiography emerged in the eighteenth century after a period of "religious incubation" during the seventeenth century, though very little scholarly attention has been paid to pre-nineteenth-century women's autobiographical writing in Italy.

48. Moreover, the lack of consistency and brevity make it difficult to classify the Giornali (which cover a total of nineteen days over nearly four years) as a true diary. Cf. Michel David, "II problema del diario intimo in Italia", in "Journal Intime" e letteratura moderna: Atti di Seminario, Trento, Marzo-Maggio 1988, ed. Anna Dolfi, Rome, Bulzoni, 1989, p. 79-107, especially p. 86.

49. Michel David further refers to the passage in the Vita in which Alfieri mentions his "kind of diary" ("una specie di diario"), again using approximative phrases such as "a study of myself" ("studio di me stesso"). See Michel David, "Il Giornale di Alfieri", in Vittorio Alfieri e la cultura piemontese fra Illuminismo e Rivoluzione, Atti del Convegno internazionale di Studi (San Salvatore Monferrato, 22-24 settembre 1983), ed. Giovanna Ioli, San Salvatore Monferrato-Cassa di Risparmio di Alessandria-Regione Piemonte, 1985, p. 62-63.

50. « Portrait», p. 10.

51. Vittorio Alfieri, Giornali, in Opere di Vittorio Alfieri ristampate nel primo centenario della sua morte, Turin, G.B. Paravia, 1903, p. 281.

52. Ibid., p. 275.

53. "This healthy examination of myself interrupted for more than two years, partly because of the great difficulty of expressing myself in Italian, and no less because of my natural disdain for speaking poorly of myself, appears before me once again as an effective means of correcting myself a bit, and at the same time of improving my style." (ibid., p. 282)

54. "Unfortunately, however, whatever might be the merit of these two tragedies, they were written in French prose, and much labor was requisite to transform them into Italian poetry. I had sketched them in this meagre and unpleasing language, not that I knew it, or even pretended 
to know it, but because during my five years' travels it was the only language I heard spoken, and because I explained myself in it better than in any other. By my ignorance of language I bore a striking resemblance to one of those noted couriers of Italy, who, when sick in bed, dreams that he runs, and wants only his limbs to surpass his rivals." (Vita scritta da esso, p. 179; Life of Vittorio Alfieri, p. 201)

55. Life of Alfieri, p. 202.

56. See Ricaldone, "Un naufragio felice: L'île di Giuseppina di Lorena-Carignano", Italies. Littérature-Civilisation-Société 2, 1998, p.135-143; "Il secolo XVIII come laboratorio della modernità", in Geografie e genealogie letterarie: Erudite, biografe, croniste, narratrici épistolieres, utopiste tra Settecento e Ottocento, ed. Adrianna Chemello, Padua, Il Poligrafo, 2000, p. 21; and "La donna forte, l'amica e la riformatrice", p. 160-161.

57. "Scrivo per me, di me e fra me" ["I write for myself, about myself, and by myself"]; Giuseppe Pelli, Efemeridi, Is. XV, 11 agosto 1765, c. 17, cited in Silvia Capecchi, Scrittura e coscienza autobiografica nel diario di Giuseppe Pelli, Rome, Edizioni di Storia e Letteratura, 2006, p. 40.

58. This is in contrast to what has been proposed by Michel David, who defined Alfieri's Giornali as the "primo diario 'intimo' italiano e uno dei primi europei" (p. 84). Capecchi has instead shown Pelli's much earlier awareness of the antithetical relationship between the private self-analysis of the diary and the public self-construction of the autobiography (p. 72).

59. On the genre of the diary in Italy, particularly with regard to Alfieri's journals, see Michel David, "II problema del diario intimo in Italia." See also Arnaldo Di Benedetto, "Questo salutare esame di me stesso: Alfieri diarista", in Le passioni e il limite. Un'interpretazione di Vittorio Alfieri, nuova edizione riveduta e accresciuta, Naples, Liguori, 1994, p. 21-35; Franco Fido, "Specchio o messaggio? Sincerità e scrittura nei giornali intimi fra il '700 e ' 800 ", in Le muse perdute e ritrovate: Il divenire dei generi letterari fra Sette e Ottocento, Florence, Vallecchi editore, 1989; and Guido Santato, "Dai Giornali alla conversione letteraria", in Alfieri e Voltaire. Dall'imitazione alla contestazione, Florence, Olschki, 1988, p. 61-67.

60. Sophia Rosenfeld has argued that the later period of the Enlightenment era might just have well been deemed "the Age of Passion", characterized by both "emotional sensibility" and "rational political argumentation"; "Thinking about Feeling, 1789-1799", French Historical Studies 32, n 4, 2009, p. 697-706 (citation at p. 700). Similarly, Denby holds as "unsustainable" the notion that "the Enlightenment was a rationalist movement hostile to sensibility and emotion - a view that reduced sensibility to an anachronistic 'pre-Romantic' phenomenon" ("Sensibility", op. cit.), and Anne Vila has argued that the dichotomy between sensibility and reason "does not at all suffice to explain the complexity of sensibility in the eighteenth century", which "had its own distinct history, one that ran parallel to that of the Enlightenment itself". (Vila, p. 302)

\section{ABSTRACTS}

Sensibilité in the eighteenth century was often associated with friendship, but friendship was mostly conceived as limited to relationships between males. The Princess of Carignano challenges this gendered distinction between friendship and love in her literary self-portrait, which documents her quest to master the passions and to prove herself capable of intellectual and emotional fellowship with members of the Italian literary elite, such as Vittorio Alfieri and Tommaso Valperga di Caluso. 
Au dix-huitième siècle, la sensibilité est souvent associée à l'amitié, considérée comme un mode de relation essentiellement masculin. La princesse de Carignano met en cause cette distinction sexuée entre amitié et amour dans son autoportrait littéraire. Elle y rend compte de sa tentative de dominer les passions et de se montrer capable d'entretenir un commerce intellectuel et affectif avec des membres de l'élite littéraire italienne, dont Vittorio Alfieri et Tommaso Valperga di Caluso.

INDEX

Mots-clés: Alfieri (Vittorio), friendship, autobiography, Caluso (Tommaso Valperga di),

Carignano (Marie Joséphine Thérèse de Lorraine), gender identity, sensibility

Keywords: Alfieri (Vittorio), amitié, autobiographie, Caluso (Tommaso Valperga di), Carignano

(Marie Joséphine Thérèse de Lorraine), identité de genre, sensibility

\section{AUTHOR}

ARIA ZAN CABOT

Southern Methodist University 